\title{
Pendampingan Pastoral Kepada Perempuan Korban KDRT di HKBP
}

\author{
Mangara Pakpahan \\ Mahasiswa Pascasarjana Sekolah Tinggi Teologi Cipanas \\ mangarapakpahan@gmail.com
}

\begin{abstract}
This research is intended to give attention to members of the congregation, especially women (wives) victims of Domestic Violence (Domestic Violence) in the HKBP church, especially HKBP Duren Sawit. Cases of domestic violence experienced by women as victims greatly affect their personal lives and relationships to others. Women victims of domestic violence suffer physical and psychological injury. This happens as a result of the violence and suffering experienced. Based on this the authors conducted research and provide assistance through pastoral assistance that is sustaining, reconciling and healing. Supporting is to strengthen women victims of domestic violence who are experiencing a crisis so that they do not dissolve in their sadness, disappointment and fear. Reconciling is helping women victims of domestic violence build and renew their relationships with God and others. Healing is overcoming the damage suffered by women domestic violence, returning to wholeness and leading it to a better direction. Sampling was carried out for five female congregation (wife) victims of domestic violence at the HKBP Duren Sawit church. Pastoral assistance from the Duren Sawit HKBP church to victims of domestic violence has never been done well and seriously. This makes the congregation of victims of domestic violence despair because of the violence and suffering they experienced, thus making it stay in a feeling of confusion and fear. As a result there are congregation victims of domestic violence who actually go outside the church, to seek protection in the hope of receiving strength and recovery. Crisis counseling is a form of service that the church can do to women victims of domestic violence, so that they can experience strengthening, reconciliation, and healing from the violence and suffering experienced.
\end{abstract}

Keywords: Domestic violence, pastoral care, violence, wife, church, counseling.

\begin{abstract}
Abstrak: Penelitian ini dimaksudkan untuk memberikan perhatian kepada warga jemaat khususnya perempuan (istri) korban Kekerasan Dalam Rumah Tangga (KDRT) di gereja HKBP, khususnya HKBP Duren Sawit. Kasus KDRT yang dialami perempuan sebagai korban sangat mempengaruhi hidupnya secara pribadi dan relasinya kepada orang lain. Perempuan korban KDRT mengalami luka secara fisik dan psikis. Hal ini terjadi sebagai dampak dari kekerasan dan penderitaan yang dialami. Berdasarkan hal inilah penulis melakukan penelitian dan memberikan pertolongan melalui pendampingan pastoral yang bersifat menopang, mendamaikan dan menyembuhkan. Menopang adalah menguatkan perempuan korban KDRT yang mengalami krisis supaya mereka tidak larut dalam kesedihan, kekecewaan dan ketakutannya. Mendamaikan adalah menolong perempuan korban KDRT membangun dan memperbarui hubungannya dengan Tuhan dan sesama. Menyembuhkan adalah mengatasi kerusakan yang dialami oleh perempuan KDRT, mengembalikan pada keutuhan dan menuntunnya ke arah yang lebih baik. Pengambilan sampel dilakukan kepada lima orang warga jemaat perempuan (istri) korban KDRT di gereja HKBP Duren Sawit. Pendampingan pastoral dari gereja HKBP Duren Sawit terhadap jemaat korban KDRT belum pernah dilakukan secara baik dan serius. Hal ini membuat jemaat korban KDRT berputus asa oleh karena kekerasan dan penderitaan yang dialaminya, sehingga membuatnya tinggal dalam perasaan kebingungan dan ketakutan. Akibatnya ada jemaat korban KDRT yang justru pergi ke luar gereja, untuk mencari perlindungan dengan harapan menerima kekuatan dan pemulihan. Konseling krisis merupakan salah satu bentuk pelayanan yang dapat dilakukan gereja terhadap perempuan korban KDRT, sehingga mereka dapat mengalami penguatan, pendamaian, dan penyembuhan dari kekerasan dan penderitaan yang dialami.
\end{abstract}

Kata kunci: KDRT, pendampingan pastoral, kekerasan, istri, gereja, konseling.

Article History

\begin{tabular}{|l|l|l}
\hline Submitted: 14 September 2020 & Revised: 28 Desember 2020 & Accepted: 31 Desember 2020 \\
\hline
\end{tabular}




\section{PENDAHULUAN}

Jika ada Tuhan, mengapa tetap ada kejahatan? Sebuah pertanyaan yang mungkin juga pernah menjadi pertanyaan kita saat mengalami penderitaan hidup: seperti yang diakibatkan oleh bencana alam, penyakit, kegagalan, kedukaan, korban kekerasan dalam rumah tangga dan lain sebagainya. Hal ini kerap membuat sebagian orang merasa bahwa Tuhan seolah-olah tidak mampu bertindak atas hidupnya. Oleh karena itu tidak sedikit orang yang kecewa kepada Tuhan dan pada akhirnya meninggalkan Tuhan. Pertanyaan itu jugalah yang penulis sampaikan terhadap posisi perempuan yang menjadi korban kekerasan apalagi di dalam rumah tangganya. Jika ada Tuhan mengapa seorang istri mengalami kekerasan dari suaminya, yang notabene adalah orang paling terdekat dan seharusnya menjadi tempat berlindung dan memberikan rasa aman baginya?

\section{METODOLOGI PENELITIAN}

Dalam menyusun tulisan ini, penulis akan menggunakan metodologi penelitian wawancara terhadap lima orang perempuan korban kasus KDRT di Jemaat HKBP Duren Sawit. Penulis juga akan menggunakan penelitian literatur untuk memperkuat kajian tinjauan terhadap korban KDRT. Dengan kedua metode tersebut penulis dapat mengkaji metode konseling krisis sebagai bentuk pendampingan pastoral yang relevan terhadap perempuan korban KDRT.

Adapun kelima konseli korban KDRT yang dijumpai oleh penulis di gereja HKBP Duren Sawit, yaitu:

1. Ibu RM, menikah dengan bapak FS. Mereka belum mempunyai anak hingga di usia perkawinan yang ke 8 tahun. Ibu RM dan suaminya tadinya tinggal serumah bersama ibu mertua. Namun seiring berjalannya waktu, ibu RM memilih tinggal bersama suaminya di rumah yang berbeda dari ibu mertuanya, di Jakarta.

2. Ibu BL, menikah dengan Bapak JP dan sudah dikaruniakan Tuhan dengan kehadiran 2 anak pada usia perkawinan yang ke 10 tahun. Anak pertama seorang perempuan berumur 9 tahun, yang sedang duduk di bangku kelas 3 SD. Anak kedua seorang laki-laki berumur 5 tahun, yang sedang duduk di bangku TK. Mereka tinggal di sebuah rumah kontrakan di Jakarta.

3. Ibu TT, menikah dengan Bapak SS dan dikaruniakan Tuhan dengan kehadiran 2 anak di usia perkawinan ke 24 tahun. Anak pertama seorang perempuan dengan nama DS (mahasiswa semester 5 di salah satu perguruan tinggi swasta 
di Jakarta). Anak kedua seorang laki-laki bernama JS (mahasiswa semester 1 di salah satu perguruan tinggi negeri di Bandung). Mereka tinggal di salah satu komplek perumahan di Jakarta.

4. Ibu RS, menikah dengan bapak BN dikaruniakan Tuhan dengan kehadiran 3 orang anak laki-laki yang bernama JIN (mahasiswa semester 2 di salah satu perguruan tinggi swasta di Jakarta), JON (siswa kelas 3 di salah satu SMA swasta di Jakarta) dan JBN (siswa kelas 1 di salah satu SMA negeri di Jakarta). Usia perkawinan mereka telah memasuki 22 tahun. Mereka tinggal di salah satu pemukiman padat penduduk rumah kontrakan di Jakarta.

5. Ibu SP, menikah dengan bapak ES dan sudah dikaruniakan Tuhan 4 orang anak dengan usia perkawinan 9 tahun. Anak pertama seorang perempuan bernama US (siswa kelas 2 di salah satu SD Negeri Jakarta). Anak kedua seorang perempuan IS (TK Besar). Anak ketiga seorang laki-laki bernama DAS (TK kecil). Anak keempat seorang laki-laki JS (bayi 2 tahun). Ibu SP tinggal bersama keluarganya di salah satu komplek perumahan di Jakarta.

\section{HASIL}

Dari kelima kasus yang telah dipaparkan di atas dapat dirangkumkan sebagai berikut:

1. Kebanyakan perempuan (istri) korban KDRT memiliki pengalaman yang sama dalam menjalani hidup rumah tangganya, dimana mereka menerima kekerasan secara fisik. Kekerasan secara fisik yang dimaksud berupa pukulan dan tamparan sebagaimana yang terjadi dalam kasus 1, 4 dan 5. Memang kekerasan fisik yang dialami perempuan korban KDRT pada kasus 2 dan 3 tidak secara langsung mengena ke bagian tubuhnya dari suaminya, akan tetapi bias dari emosi yang tidak terkendali dari suaminya, membuat barang-barang perabotan di rumah mereka banyak yang rusak. Ditambah lagi sikap yang ditunjukkan para suami yang gemar mabuk-mabukan (kasus 1, 2 dan 3), suami yang suka pulang berlarut-larut malam tanpa konfismasi ke istri (kasus 1, 2, 3 dan 4), suami yang suka selingkuh (kasus 1 dan 4), suami yang suka mengkonsumsi narkoba (kasus 1 dan 2), serta suami yang tidak bertanggung jawab secara finansial (kasus 1, 2, 3, dan 4) yang semakin memperpuruk keadaan, membuat para istri (perempuan) korban KDRT menjadi lebih gigih berjuang dengan bekerja (terdapat di semua kasus). 
2. Selain menerima kekerasan secara fisik, perempuan (istri) korban KDRT pada kelima kasus di atas juga menerima kekerasan secara psikis. Kata-kata hinaan yang diterima dari suami dan juga ibu mertua, membuat para istri korban KDRT menjadi semakin menambah beban pikiran, depresi, stress seperti yang terjadi atas semua kasus di atas. Tidak hanya itu, mereka pun menjadi pribadi yang tertutup (kasus 2, 3 dan 4), mengalami ketakutan yang selanjutnya kita sebut dengan trauma (kasus 1, 2, 4 dan 5), akibat dari perlakuan para suami terhadap mereka.

3. Perempuan korban KDRT pada akhirnya menyadari kenyataan pahit yang dialaminya dari perlakuan suaminya, sehingga memiliki sikap hanya mampu pasrah dan berserah sepenuhnya kepada Tuhan (kasus 2, 4 dan 5). Walaupun demikian, masih ada juga mereka yang menjadi korban KDRT tidak mampu menerima kenyataan hidupnya atas perlakuan suami mereka, seperti pengalaman ibu RM pada kasus 1. Di sisi lain, ada pula mereka yang menjadi putus harapan, seolah-olah merasa bahwa hidupnya tidak berarti lagi dan akan segera berakhir, seperti pengalaman ibu BL pada kasus 2.

4. Pemicu terjadinya KDRT kebanyakan disebabkan oleh karena ketidakmampuan para suami dalam memenuhi tugas dan tanggung jawab secara finansial (kasus 1, 2, 3 dan 4). Peran suami sebagai kepala keluarga seharusnya dapat bertanggungjawab untuk memenuhi kebutuhan hidup seharihari dalam keluarga tersebut. Salah satu kematangan penting yang dituntut dari seorang suami adalah kematangan secara ekonomi, yaitu memiliki profesi dan pekerjaan tertentu sehingga ia mampu menghasilkan finansial yang memadai untuk memenuhi seluruh keperluan rumah tangga. Kematangan tersebut sangat diperlukan untuk menjamin atau memenuhi kebutuhan istri dan anakanak dalam rumah tangga.

\section{PEMBAHASAN}

\section{Tinjauan Teoritis Terhadap Kekerasan dalam Rumah Tangga}

\section{Analisa Psikologis}

Dari pengalaman para konseli di atas, penulis menemukan dampak psikologis dari KDRT yaitu depresi dan trauma. Hampir semua kasus dari pengalaman perempuan korban KDRT tadi menunjukkan reaksi yang serupa yaitu mengalami depresi. Yulia Singgih mengatakan bahwa depresi menjadi salah satu bentuk penyaluran rasa kesal/tekanan batin yang sering terlihat pada kaum ibu dan 
perempuan (Gunarsa \& Gunarsa, 2012). Kesal karena menghadapi suami yang tidak sesuai dengan yang diharapkan, tidak memahaminya, tidak menghargai, tidak bertanggungjawab, bersikap kasar, selingkuh, minum-minuman keras, dunia malam, menggunakan obat terlarang. Perasaan kesal yang menumpuk akhirnya meluas pada segi emosionalitas dan disebut tekanan jiwa (Gunarsa \& Gunarsa, 2012).

Depresi yang berlangsung cukup lama dapat mengganggu fungsi tubuh atau fungsi vegetatif seperti tidak selera makan hingga mengakibatkan turunnya berat badan (Greist \& Jefferson, 1998). Demikianlah depresi yang dialami para korban KDRT dalam kasus yang dapat ditemukan dari sikap kasus BL yang mau menjual ginjalnya demi membayar hutang-hutang suaminya karena mengkonsumsi narkoba. Di samping itu $B L$ juga sering gemetaran, merasa sangat lemas, tangan berkeringat. Demikian juga dengan pengalaman RM yang sering dibayang-bayangi oleh rasa takut yang berlebihan sehingga mengganggu tidurnya dan sering menangis dan gemetaran. TT juga mengalami hal ketakutan yang berlebihan yang mengakibatkannya trauma melihat benda yang dipakai oleh suaminya. Pengalaman depresi itu senada dengan yang dikatakan oleh Namora Lumongga Lubis tentang gejala-gejala depresi yang ditunjukkan melalui gejala fisik, psikis dan sosial (Lubis, 2016).

Di samping itu, KDRT juga dapat mengakibatkan trauma. Karl dan Evelyn Bartsch, mengatakan bahwa trauma merupakan kejadian mengejutkan yang sangat menyakitkan-tajam mengiris, dan terjadi di luar pengalaman manusia pada umumnya sehingga mengakibatkan rasa takut pada siapa saja yang mengalaminya (Karl \& Bartsch, 2005). Koentjoro dan Budi Andayani, mengatakan bahwa trauma adalah memar secara psikologis (Koentjoro \& Andayani, 2007). Trauma yang diakibatkan kekerasan dalam rumah tangga termasuk dalam jenis trauma berulang, sebab kekerasan yang dilakukan berulang kali itulah yang membuat korban mengalami trauma. Sebagaimana teori siklus kekerasan atau lebih dikenal "Teori Lingkaran Kekerasan" yang diungkapkan oleh Lenore Walker, yakni sebuah siklus yang dimulai dengan konflik - kekerasan - berdamai - rujuk/bulan madu (Walker, 1979). 


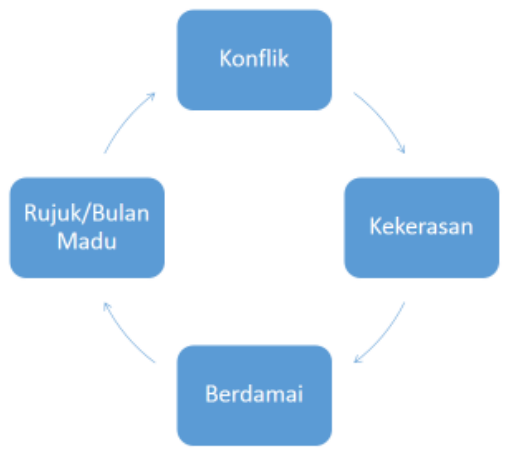

Menurut Dena Rosenbloom, dkk., trauma dapat mempengaruhi seluruh kehidupan seseorang, termasuk perubahan dalam tubuh, pikiran, emosi, dan perilaku. Tetapi reaksi yang spesifik pada setiap orang tergantung pada latar belakang setiap orang, hubungan sosial, usia pada saat mengalami trauma, dan faktor-faktor pendukung lainnya selama mengalami trauma (Rosenbloom et al., 2010). Stres dan trauma yang dialami akibat kejadian hebat menimbulkan perasaan sakit pada seseorang, baik fisik maupun mental, dan bahkan sering menyebabkan beberapa gangguan emosional atau psikologis dikemudian hari; yang disebut dengan "Post Traumatic Stress Disorder" (PTSD) atau gangguan stress pasca trauma. Orang yang mengalami PTSD umumnya "dihantui" pengalaman traumatis yang mereka alami baik langsung maupun tidak langsung (Hatta, 2016). Oleh karena itu kekerasan yang dialami seorang perempuan dalam rumah tangganya akan membuatnya menjadi seorang yang eksklusif dan tidak bisa lagi mempercayai orang lain di luar dirinya sendiri.

\section{Analisis Sosial Budaya}

\section{a) Budaya Partiarki}

Budaya Batak adalah salah satu dari sekian banyak budaya yang menganut sistem garis keturunan laki-laki (Patrilinieal) di mana menganggap bahwa nilai, posisi dan peran laki-laki lebih tinggi dari pada perempuan dalam tatanan masyarakat Batak (SEAGEST, 1993). Adanya hierarkhi ini membuat kesenjangan yang sangat kontras antara laki-laki dan perempuan dalam keluarga Batak. Contohnya: laki-laki selalu diutamakan dalam segala hal, baik pendidikan maupun warisan. Menurut Benyamin, kekerasan yang begitu banyak dan luas mempunyai akar struktural dan dilandasi ideologi partiarki yang menempatkan perempuan di bawah dominasi laki-laki, sehingga laki-laki menjadi 'dipertuan' dan perempuan menjadi 'diperhamba' (Bria, 
2003). Pemahaman tersebut akhirnya membuat hierarki bahwa laki-laki lebih tinggi, superior dibanding perempuan. Laki-laki dianggap memiliki kekuasaan (power). Pemahaman itulah yang juga mempengaruhi para pelaku sebagai kepala keluarga sehingga merasa berhak atas hidup istrinya. Laki-laki (Suami) merasa memiliki kuasa di rumah tangganya dan penentu segala sesuatu dalam keluarga sedangkan istri dianggap sebagai seseorang yang harus menuruti semua perintah suami.

Selain menganut budaya patriarkhal atau melanjutkan garis keturunan laki-laki (agnate), orang Batak juga mengenal hubungan perkawinan (affinity) (Nainggolan, 2012). Dalam perkawinan Batak, pihak pemberi istri (hulahula) adalah sumber kehidupan bagi pihak penerima istri (boru), sebab si istri lah yang akan memberikan garis keturunan kepada setiap marga suaminya. Sehingga pihak pemberi istri dianggap mempunyai kuasa sahala karena menjadi penentu untuk memberi garis keturunan bagi marga lain (Nainggolan, 2012). Dan sebagai penghormatan kepada hulahula maka sebagai ganti dari putri mereka maka pihak laki-laki akan memberikan tuhor, artinya tukar. Tuhor ini juga sering disebut mahar sebagai ganti dari putri yang diberikan kepada pihak laki-laki. Karena itu perempuan sering sekali dianggap rendah karena sudah dibeli oleh pihak laki-laki sehingga ada kesan boleh memperlakukan perempuan dengan semena-mena.

Dengan pertimbangan-pertimbangan tersebut maka seseorang yang mengalami KDRT di keluarganya akan memilih untuk bertahan daripada tidak dianggap dalam kekerabatan orang Batak. Demikian juga para korban KDRT yang mempertahankan pernikahannya demi anak-anak agar tetap diperhitungkan dalam struktur budaya meskipun struktur itu membebaninya. Anak-anak tanpa ayah akan jauh lebih mengorbankan masa depan mereka dalam proses perkembangan selanjutnya ditengah keluarga dan masyarakat Batak. Korban masih merasa bahwa keberadaan suaminya sebagai ayah dari anak-anaknya masih sangat dibutuhkan meskipun tidak seperti yang diharapkan.

\section{b) Budaya Malu dan Dispilin Gereja HKBP}

Kekerasan dalam rumah tangga tentunya tidak dapat ditolerir apapun alasannya. Dalam teologi perkawinan sangat jelas bahwa yang menjadi dasar perkawinan adalah cinta kasih Allah yang mempersatukan laki-laki dan perempuan menjadi satu daging. Oleh karena itu Allah tentunya tidak menghendaki terjadinya kekerasan dalam rumah tangga. Setiap keluarga Kristen harus selalu dipenuhi oleh cinta kasih sehingga semua anggota keluarga merasakan kasih dan damai Tuhan. Gereja HKBP memaknai perkawinan sebagai rencana Allah yang kudus dan tidak 
boleh diceraikan manusia. Hal itu juga dituangkan dalam salah satu perangkat pelayanan HKBP, yaitu hukum penggembalaan dan siasat gereja (RPP).

Dalam RPP tersebut ditegaskan bahwa setiap orang yang bercerai akan dikenakan sanksi atau hukum siasat gereja, yaitu dikeluarkan dari keanggotaan jemaat gereja tersebut (HKBP, 2000). Mereka akan digembalakan secara terpisah dari persekutuan jemaat. Hal ini bertujuan agar yang bersangkutan, selain memiliki rasa malu juga menyesali perbuatannya sehingga diharapkan ke depannya mengalami perubahan.

Menurut Binsar J. Pakpahan, dalam masyarakat yang menganut orientasi malu ketika hukuman diberikan, maka mereka secara publik akan dipermalukan (Pakpahan, 2016). Dengan demikian pelaksanaan hukuman bagi mereka yang melanggar RPP sebagai orang Batak sama halnya dengan mempermalukan dirinya sendiri. Bukan hanya kepada orang yang bersangkutan, tetapi juga kepada kerabatnya dan keluarganya. Selama dalam pengucilan, orang yang mendapat hukuman dianjurkan agar tetap mengikuti ibadah, tetapi tidak berhak untuk menerima Perjamuan Kudus dan Baptisan Kudus bagi anak-anaknya (HKBP, 2013). Bahkan segala kewajiban dan tanggungjawabnya sebagai warga jemaat tidak boleh diterima, misalnya ucapan syukur. Biasanya teknis pelaksanaan RPP tersebut dilakukan dengan diwartakannya nama yang dikenakan hukum siasat di tengah-tengah jemaat dalam ibadah Minggu. Pewartaan ini dimaksudkan sebagai pembelajaran bagi warga jemaat lain sekaligus mempermalukan mereka yang salah supaya malu terhadap tindakannya. Karena itu RPP menjadi hukum sosial yang sangat dihindari oleh setiap jemaat.

Peraturan gereja tentang perceraian tersebut menjadi salah satu pertimbangan besar bagi para korban KDRT mencoba untuk tetap menjadi istri yang setia meskipun hidup dalam lingkaran kekerasan. Di samping itu bagi masyarakat Batak masih merupakan sesuatu yang tabu (bahasa Batak: tongka) jika memberitahukan keburukan atau ketidakberesan rumah tangganya pada orang lain karena dianggap aib yang mempermalukan keluarganya sendiri. Oleh karena itu mereka lebih memilih untuk hidup dengan kekerasan dalam rumah tangganya daripada mengalami rasa malu terhadap semua orang, keluarga, kerabat dan juga saudara seiman di gereja yang mungkin akan dialami seumur hidupnya. Karena perasaan malu yang akan dihadapi seolah-olah dianggap menjadi sesuatu persoalan yang akan semakin menekan hidupnya. 


\section{Tinjauan Teologis terhadap Perempuan Korban KDRT}

\section{Perempuan Korban Kekerasan menurut Kisah Perbuatan Noda di Gibea (Perspektif Teologi dari Narasi Hakim-hakim 19:1-30)}

Kisah tentang perbuatan noda di Gibea merupakan gambaran kisah perempuan yang menjadi korban kekerasan, terutama atas kasus kekerasan seksual. Cerita ini dimulai dengan orang Lewi pergi ke Betlehem dan mendapatkan gundik disana. Cerita ini penuh dengan ironi yang dramatis (Bergant \& Karris, 2014). Di tengah perjalanan dari Betlehem mereka bermalam di Gibea. Di sana mereka disambut oleh seorang tua dengan keramahannya memberi tempat istirahat bagi mereka (Hak. 19:22). Tiba-tiba datanglah berandalan yang mengepung rumah itu (Hak. 19:22). Orangtua itu sengaja memberikan gundik orang Lewi dan anak perempuannya sendiri untuk diperkosa oleh berandalan itu (Hak. 19:24). Sepertinya orang tua itu juga hendak menghindari kejadian seperti yang pernah terjadi di Sodom yaitu kejahatan seksual abnormal (homo seksual, sesama jenis) sehingga ia sampai rela menawarkan anak perempuannya dan perempuan gundik orang lewi tersebut (Auld, 2017).

Kelompok berandalan tersebut pun mengambil gundik orang Lewi karena merupakan perempuan yang berasal dari Betlehem - Yehuda dan mereka semua memperkosanya sampai mati (Hak. 19:1, 24). Bagi perempuan yang disebut gundik tersebut, malam itu adalah malam yang sangat mengerikan. Karena sakit hati dan ingin membalas dendam orang Lewi itu pun melakukan mutilasi atas mayat gundiknya itu dan mengirimkannya pada 12 suku Israel (Hak. 19:29). la berharap bahwa ke-12 suku Israel itu akan menjadi musuh suku Benyamin (Bergant \& Karris, 2014).

Menurut hemat penulis kisah perbuatan noda di Gibea ini menimbulkan kesan betapa kuatnya sistem patriarki sehingga perempuan tidak mempunyai kesempatan untuk berbicara bahkan ia tidak mempunyai kesempatan untuk membela diri dan mempertahankan kehidupannya. Bahkan sebagai korban, ia tidak bisa mengungkapkan kepedihan hatinya. Dari kisah anak perempuan yang akan dikorbankan ayahnya demi keselamatan ayahnya sendiri dan orang Lewi tersebut, memberikan kesan bahwa martabat perempuan tidak layak untuk dipertahankan dalam masyarakat. Perempuan adalah seonggok daging serba guna bagi pemiliknya. Anak perempuan yang belum menikah adalah kepunyaan ayahnya. 


\section{Keberpihakan Yesus terhadap Perempuan Korban Kekerasan (Perspektif}

\section{Teologi dari Narasi Injil Yohanes 7:53- 8:11)}

Narasi Perempuan yang berzinah ini merupakan salah satu perikop yang kontroversial sebab seolah-olah Yesus mentolerir perbuatan dosa perempuan itu sehingga menyelamatkannya dari serangan para ahli Taurat dan orang Farisi yang mau menghukumnya saat itu. Tetapi Yesus justru membiarkannya pergi tanpa hukuman apapun. Yesus adalah sosok yang sangat mengasihi setiap orang berdosa dan tidak menghakimi mereka yang berdosa tetapi mengampuninya dengan penuh kasih.

Namun disamping pesan itu ada satu hal menarik dari kisah seorang perempuan berzinah yang dianggap pendosa namun juga sebagai korban dari kekerasan. Fiorenza dengan metode penafsiran wisdom ways dapat menolong kita untuk lebih jauh melihat bagaimana kekerasan dan ketidakadilan yang dialami perempuan dalam narasi itu (Fiorenza, 2001). Pertama yaitu judul perikop "Perempuan Berzinah". Dari judulnya saja memang sudah memberikan kesan kepada setiap pembaca bahwa perempuan itu sungguh-sungguh telah berbuat zinah. Padahal bagaimana kebenaran peristiwa perzinahan itupun tidak ada penjelasan lebih lanjut dari narasi itu. Dari terjemahan bahasa Batak narasi itu diberi judul "Boruboru na Targombang". Dengan sederhana dari istilah tersebut terkandung makna bahwa perempuan itu dijerat dalam sebuah kasus perzinahan. Perempuan itu sengaja dipakai atau dijerat dalam perzinahan karena dipaksa oleh laki-laki itu, dengan kata lain diperkosa hanya untuk mencari celah Yesus. Nyatanya, Ahli Taurat membebaskan laki-laki itu begitu saja dan tidak diikutsertakan dalam pengadilan. Mengapa harus perempuan? Mengapa bukan laki-laki? Karena perempuan dianggap lemah, tidak berdaya, tidak memiliki hak apapun bahkan hak untuk berbicara, perempuan tidak memiliki ruang, baik di domestik apalagi di publik.

Kedua, Sikap Yesus. Sejak pertama kali perempuan yang kedapatan berzinah itu diperhadapkan kepada Yesus, terlihat sikap yang seolah-olah tidak perduli kepada apa yang terjadi terhadap perempuan itu yang saat itu hidupnya sangat terancam. Yesus tidak sedikitpun memberikan ruang, kesempatan bagi perempuan itu untuk berbicara menjelaskan kejadian yang sebenarnya dan membuat pembelaan atas dirinya sendiri. Yesus hanya mendengarkan sebelah pihak, yaitu keterangan dari Orang-orang Farisi dan Ahli Taurat itu. Bahkan ketika orang Farisi dan ahli Taurat itu menjelaskan kesalahan perempuan itu lalu mereka meminta pendapat Yesus dengan bertanya: "Apakah pendapat-Mu tentang hal itu?" Yesus justru membungkuk lalu 
menulis dengan jari-Nya di tanah. Dan la melakukannya dua kali. Beberapa Bapa gereja seperti Eusebius dan Grotius, mengatakan bahwa cara menulis di tanah merupakan salah satu cara untuk berspekulasi tentang apa yang dituliskannya dan merupakan hal yang biasa dilakukan oleh orang bijak untuk mengalihkan pikiran orang lain terhadap yang dituliskannya (Henry, 2000).

Dalam situasi demikian, tidak ada seorangpun yang membela perempuan itu, bahkan Yesus pun tidak. Sikap Yesus yang hanya diam dan menulis-nulis di tanah semakin membuat perempuan itu putus asa, kecewa dan pasrah. Namun Yesus justru membuat Orang Farisi dan Ahli Taurat tidak dapat berkata apa-apa bahkan tidak menghukum perempuan itu setelah la berkata di ayat 7; "Barangsiapa di antara kamu tidak berdosa, hendaklah ia yang pertama melemparkan batu kepada perempuan itu". Perkataan Yesus itupun awalnya pasti membuat perempuan itu takut dan merasa bahwa ia pasti akan mati. Namun segera setelah perkataan Yesus itu situasi menjadi hening karena Orang Farisi dan Ahli Taurat itu pun pergi satu persatu dimulai dari yang tertua (ay. 9).

Jika kita melihat narasi ini secara keseluruhan, maka kita akan menemukan sikap Yesus yang sebenarnya sangat arif, bijaksana dan membebaskan bagi perempuan itu. Kesan terhadap Yesus yang seolah tidak peduli dengan perempuan itu terjawab di akhir narasi ini. Di ayat 10 inilah kali pertama Yesus berbicara kepada perempuan itu selama peristiwa itu terjadi. Yesus menegor perempuan itu justru setelah keadaan aman terkendali. Jawaban singkat dari perempuan itu menggambarkan situasi trauma yang mungkin masih membuatnya takut atas kejadian yang baru dialami itu belum membuatnya merasa tenang. Jangan-jangan yang dipikirkan perempuan itu saat itu Yesus yang akan melemparinya sampai mati karena ia masih diliputi rasa takut. Apa yang dialami perempuan itu memang sangat mengerikan, dan wajar membuatnya trauma sehingga membuatnya tidak bisa berkata banyak karena ia tidak menyangka bahwa hidupnya bisa selamat dari pengadilan yang mengerikan itu.

\section{Teologi Kekerasan}

Tidak dapat disangkal, bahwa Alkitab yang selama ini kita yakini menjadi bahan dasar pemahaman teologis kita, ditulis dan dikanonkan di tengah-tengah masyarakat patriarkal. Dalam corak konstruksi budaya yang demikian, maka bahasa, muatanmuatan dan isi Alkitab sangatlah partiarkal atau sangat memihak kepada kaum lakilaki dan menempatkan perempuan sebagai subordinasi laki-laki. Misalnya; perempuan 
tidak berhak atas warisan (Bil. 27:1-11), perempuan dipoligami (Kej. 16, 29, 30), perempuan boleh diusir dari rumah dan diceraikan dengan mudah (Im. 12:9), keperawanannya diuji (Ul. 22:13-19), ada masa najis (Im 12:1-5), perempuan tidak boleh bicara di gereja (1 Tim. 2:12; I Kor 14:34-35), istri menundukkan diri pada suami (Kol 3:18-4:1), dan yang lainnya. Dengan demikian penafsiran dan pengaplikasiannya pun sarat dengan roh partiarkal. Bahkan tidak jarang teks Alkitab ini dijadikan alat untuk mensahkan dominasi laki-laki atas perempuan sehingga perempuan menjadi korban masyarakat yang andosentrisme.

Selama berabad-abad, gereja mengembangkan teologinya sejalan dengan pola pikir patriarkal yang membahayakan perempuan karena menyangkal martabat perempuan sebagai ciptaan Allah yang diciptakan menurut citra Allah, sebagaimana laki-laki. Sistem patriakal yang sangat kuat itu yang mengakibatkan perempuan mengalami kekerasan baik secara fisik maupun psikis. Sistem patriarkal itu telah membentuk cara pandang semua orang terhadap perempuan itu sehingga memperlakukannya seperti 'alat' atau 'barang' bukan sebagai manusia yang seharusnya dihormati. Perempuan dianggap sebagai objek yang pantas untuk dieksploitasi demi kepentingan tertentu. Bahkan jangan-jangan seseorang yang dilahirkan sebagai perempuan dianggap menjadi sebuah kesalahan atau dosa. Jadi jika perempuan itu mati, tidak memberikan dampak apa-apa dalam sistem patriarki. Dan ini adalah teologi kekerasan karena mendorong pelanggaran hak-hak perempuan dan secara spiritual membunuh kaum perempuan. Teologi kekerasan juga mengubur potensi, talenta dan kreativitas perempuan melalui peran-peran steorotipe domestik sehingga perempuan kehilangan kebebasannya untuk hidup sebagai citra Allah sebagaimana dimaksudkan oleh Allah (Kej. 1:26-28) (Ririmasse, 2019). Teologi ini justru menempatkan perempuan sebagai mahluk subordinat dan karenanya hakhaknya bisa dilanggar. Di sisi lain, teologi ini menempatkan kaum laki-laki sebagai manusia yang beruntung karena Allah menciptakan mereka sebagai manusia utuh dan menganugerahi mereka keistimewaan termasuk dominasi terhadap perempuan.

Untuk mendekonstruksi teologi tersebut diperlukan cara pandang yang baru yang dapat meningkatkan spiritualitas masyarakat menjadi lebih adil dan setara. Pengalaman-pengalaman kekerasan yang dapat melukai setiap orang baik laki-laki dan perempuan harus mendorong mereka menemukan gambar Allah (Imago Dei). Oleh karena itu kita harus sungguh-sungguh memahami Allah menciptakan manusia baik laki-laki dan perempuan adalah sama, segambar dengan citra Allah (Imago Dei) (Ririmasse, 2019). Jika demikian maka sesungguhnya tidak ada celah bagi laki-laki 
sebagai kepala keluarga untuk menganggap dirinya lebih tinggi dari perempuan sehingga memberikan hak kepada laki-laki untuk semena-mena terhadap perempuan dan merasa berkuasa atas perempuan atau istrinya.

Dalam menyikapi kekerasan, Yesus juga telah mengubah cara pandang semua orang kepada perempuan, bahwa perempuan adalah manusia yang harus dihormati, dihargai dan dikasihi. Itulah juga seharunya yang menjadi acuan kita bersama dalam menyikapi kekerasan yang dihadapi perempuan dalam rumah tangganya. Walaupun kita hidup dalam budaya patriarkal, membangun perkawinan di dalam budaya itu tetapi Yesus tidak mengendaki kita untuk menempatkan perempuan didominasi oleh laki-laki. Budaya patriarkal tidak dapat melegalkan laki-laki untuk berkuasa atas perempuan sehingga budaya dianggap menjadi alasan laki-laki untuk berbuat semena-mena terhadap perempuan.

Dengan menemukan kesetaraan antara laki-laki dan perempuan debagai gambar Allah, tentunya akan membangun dan mentransformasi spiritualitas kita yang bertumpu pada Imago Dei yang membebaskan manusia dari belenggu-belenggu budaya patriarki yang dapat mengakibatkan kekerasan. Spiritualitas tersebut juga akan mendorong masyarakat untuk memperjuangkan kesetaraan dan keadilan sehingga kekerasan akan dianggap menjadi musuh bersama yang harus dihancurkan.

\section{Teologi Penderitaan}

Istilah "Teologi Penderitaan" dapat dipakai dalam dua pengertian. Pertama, istilah ini dapat merujuk pada paham yang mengharuskan setiap orang Kristen untuk menderita selama di dunia supaya memperoleh kekayaan dan kebahagiaan sorgawi. Kedua, istilah ini juga seringkali digunakan dalam arti pandangan Alkitab (konsep Teologis) tentang berbagai seluk-beluk penderitaan. Pengertian yang kedua tersebut mencakup diskusi seputar asal-usul penderitaan, kaitan penderitaan dengan eksistensi Allah (apakah penderitaan membuktikan bahwa Allah tidak ada atau tidak baik?), tujuan penderitaan dalam perspektif teologi tertentu maupun penjelasan tentang mengapa orang-orang benar mengalami penderitaan. Banyak orang masih meyakini bahwa karena Yesus menderita dan mati di kayu salib, maka para pengikutNya juga harus menjadikan penderitaan sebagai bagian dari kehidupan mereka. Memang, salib dan kebangkitan Kristus adalah intisari iman Kristen dan ini mendasari pengharapan orang beriman (Moltman, 1993b).

Menurut Moltman, titik pusat kekristenan adalah perjumpaan dengan Yesus Kristus yang disalibkan, mati dan bangkit. Dalam perjumpaan ini, pada satu sisi kita 
menjumpai Tuhan yang merendahkan diri-Nya menjadi manusia dan membiarkan diriNya dalam penderitaan yang tidak berbelaskasihan, mati di dalam keadaan yang ditinggalkan Allah pada salib (Moltman, 1993a). Iman Kristen hidup dari kebangkitan Kristus yang disalibkan dan mendambakan masa depan Kristus yang akan terpenuhi dalam parusia. Pada salib Kristus, kematian manusia mendapat arti bagi Allah. Yesus yang mati di kayu salib dirasakan baik oleh Allah Bapa (Moltman, 1993a). Dengan kata lain, penderitaan dipandang sebagai suatu bentuk pietisme Kristen. Spiritualitas semacam ini tidak hanya menuju ke arah personal dan sekaligus "ke dalam batin" (inward looking), akan tetapi bisa juga menjadi problematis (Ririmasse, 2019). Artinya, pandangan problematis karena menyangkut penderitaan tanpa pandang bulu sehingga melegitimasikan sumber-sumber penderitaan termasuk masalah ketidakadilan. Jenis spiritualitas semacam ini hanya menekankan pertumbuhan yang personal, dan mengabaikan kebutuhan keadilan dan perdamaian dalam masyarakat.

Perempuan yang dilecehkan oleh suaminya, dianiaya dan diperkosa dalam rumah tangga atau tempat kerja, yang martabat dan haknya dilanggar oleh negara, adalah korban yang sangat menderita. Namun penderitaan mereka tanpa arti dan tujuan, karena mereka tak tahu mengapa dan untuk apakah mereka harus menderita. Ini adalah penderitaan yang pasif, yang bagi perempuan korban sungguh tak bernilai sebab mereka menderita tanpa martabat. Karenanya kepada para perempuan korban kekerasan, kita tidak bisa mengatakan "pikullah salibmu dengan sabar karena Yesus sudah melakukannya dalam hidupNya" (Ririmasse, 2019).

Oleh karena itu penderitaan tidak bisa dijadikan sebagai pilihan hidup terbaik bagi para pengikut Yesus, sebaliknya justru penderitaan harus disingkirkan dari dunia dengan mendirikan tanda-tanda Kerajaan Allah, tempat keadilan dan dan perdamaian tersemai, sehingga tak seorang pun harus memikul kembali salib demi kehidupan orang lain seperti yang telah dilakukan oleh Yesus. Namun salib tetap perlu dijadikan pokok acuan, yakni bila demi mentransformasikan struktur sosial yang tak adil kita harus menderita, maka kita harus mengikuti langkah Yesus, memikul salib dengan kerelaan (Ririmasse, 2019). Inilah dinamika penderitaan yang tercermin pada Yesus.

Penderitaan bukanlah kehendak Allah bagi ciptaanNya. Penderitaan perempuan yang diakibatkan oleh kekerasan justru harus dilihat sebagai perbuatan dosa yang dilakukan terhadap Allah dan korban. Oleh karena itu penderitaan harus dilenyapkan dari tengah-tengah dunia, namun dinamikan penderitaan tetap dibutuhkan, dalam arti sejauh praktik ketidakadilan dan kejahatan tetap berlangsung di dunia saat ini, maka dinamika penderitaan dibutuhkan untuk melenyapkan. 


\section{Pendampingan Pastoral terhadap Perempuan Korban KDRT dengan Metode Konseling Krisis}

Perempuan yang pada umumnya menjadi korban KDRT tentu mengalami krisis yang sangat menekan hidupnya sehingga ia butuh ditolong. Pendampingan dan konseling pastoral menjadi salah satu peran gereja bagi mereka yang bergumul karena KDRT. Secara tradisional dalam kehidupan gerejawi kita, pastoral merupakan tugas "pendeta", yang harus menjadi gembala bagi jemaat atau "domba" nya (Beek, 2014).

Daniel Susanto mengutip pendapat William A. Clebsh dan Charles R. Jaekle, mengatakan bahwa ada empat fungsi dasar pastoral di sepanjang sejarah gereja, yaitu: menyembuhkan (healing), menopang (sustaining), membimbing (guiding), dan mendamaikan (reconciling). Howard Clinebell, kemudian menambahkan fungsi yang kelima, yaitu memelihara (nurturing) (Susanto, 2020). Namun dari kelima fungsi pastoral tersebut, menurut hemat penulis setidaknya ada tiga fungsi pastoral yang dapat dilakukan dalam pendampingan terhadap perempuan korban KDRT yaitu, menopang (sustaining), mendamaikan (reconciling), dan menyembuhkan (healing).

Untuk menolong perempuan-perempuan korban KDRT dan mencapai fungsi pastoral tersebut, maka menggunakan metode konseling krisis melalui tahapan Metode ABC yang mencakup tiga tahap: $A=$ Achieve contact with person (mencapai hubungan dengan pribadi); $B=$ Boiling down the problem to its essential (memfokuskan masalah pada bagiannya); $C=$ Cope actively with the problem (menanggulangi masalah secara aktif) (Stone, 1993).

Korban KDRT tentu berada dalam krisis sebagaimana pengalaman ibu RM, BL, TT, RS dan SP dalam deskripsi kelima kasus KDRT bab II, dimana mereka mengalami krisis pasca terjadinya kekerasan. Ketika mereka merasa tidak sanggup lagi menghadapi situasi tersebut disitulah mereka mengalami krisis (Subagyo, 2003). Meskipun agak sedikit sulit bagi budaya Batak untuk menyampaikan persoalan rumah tangganya kepada orang lain, namun penulis mencoba menggunakan metode ini karena dari pengalaman penulis menghadapi jemaat yang datang kepada penulis menyampaikan semua yang terjadi dalam rumah tangganya. Konseli tersebut tentu memberanikan dirinya karena ia tidak sanggup lagi menghadapi kekerasan yang dialami. Itulah sebabnya penulis membuat metode konseling krisis ini. 


\section{Mencapai hubungan dengan pribadi yang mengalami krisis}

\section{(Achieve contact with person)}

Proses ini merupakan kunci awal bagi keberhasilan konseling, karena pada tahap ini, pendamping dituntut untuk dapat membangun kepercayaan orang yang didampingi (konseli). Oleh karena itu tentu seorang konselor (pendeta) harus memiliki keterampilan khusus dalam menghadapi pelayanan-pelayanan khusus seperti ini supaya dapat memberikan konseling secara benar dengan keahlian yang dapat menolong jemaatnya dari krisis yang sedang dihadapi (Beek, 2014). Ibu RM merupakan salah satu jemaat korban KDRT yang mengawali komunikasi dengan penulis sebagai pendeta. Komunikasi itu dimulai melalui telepon ibu RM kepada penulis. Sebelumnya penulis memang sudah diberitahu oleh pimpinan jemaat, bahwa akan ada jemaat yang minta untuk dilayani konseling. Penulis sudah menyiapkan waktu pada hari yang telah ditentukan, untuk menerima telepon hingga perjumpaan di konsistori gereja. Percakapan awal di telepon pun, ibu RM sudah langsung banyak bercerita tentang persoalan rumah tangganya, penulis tetap mendengarkannya sampai ibu RM selesai berbicara. Pada akhirnya ibu RM meminta untuk dapat bertemu dengan penulis. Dalam hal ini Wright, mengatakan bahwa konselor perlu mengajukan beberapa pertanyaan melalui telepon tersebut sehingga dapat menolong konselor untuk menentukan seberapa mendesaknya keadaan konseli dan apakah hal itu benarbenar merupakan krisis. Jika demikian maka konselor dapat mengatur pertemuan pertama dan menentukan siapa-siapa saja yang hadir dalam pertemuan itu (Wright, 2006). Awal pembicaraan lewat telepon, penulis memang sudah mengendalikan percakapan tersebut, yaitu supaya ibu RM tetap tenang dan mengatur waktu boleh melanjutkan percakapan kemudian dalam pertemuan tatap muka. Ibu RM menyambutnya dengan baik, karena itulah yang memang diharapkannya dapat bertemu dengan pendeta. Sebab jika penulis memilih lebih banyak mendengar saja, maka ibu RM mungkin akan menjadi ragu untuk meminta pertolongan dari penulis, sehingga pertemuan berikutnya tidak akan terjadi.

Untuk membangun komunikasi dengan ibu RM, penulis menyarankan untuk merencanakan perjumpaan dengan konseli di ruang konsistori gereja. Hal itu sangat penting dalam membangun hubungan dengan konseli yang memerlukan perjumpaan secara pribadi. Dalam pelayanan di setiap gereja khususnya di perkotaan yang pada umumnya memiliki jumlah jemaat yang besar, hampir setiap gereja mempersiapkan ruangan atau kantor untuk masing-masing pendeta. Ruangan tersebut dibuat supaya pendeta itu dapat mengerjakan persiapan pelayanannya (misalnya mempersiapkan 
pelayanan kategorial, dll) dan juga menjadi tempat bagi jemaat yang datang untuk melakukan konseling. Sehingga para pendeta di perkotaan pada umumnya setiap hari hadir di gereja karena selalu ada jemaat yang datang, baik tanpa janji maupun dengan berjanji lebih dahulu melalui telepon. Namun bagi penulis, konsistori menjadi salah satu tempat yang sangat baik dan paling aman untuk dilakukannya perjumpaan dengan konseli. Sebab jika dilakukan di luar konsistori misalnya, di kantor pribadi, di rumah, di restoran atau tempat lain bisa saja membuat ketidaknyamanan baik bagi penulis sebagai konselor yang adalah laki-laki dan juga kepada konseli (perempuan).

Pada tahap ini tentu sikap konselor sangat menentukan konseli dalam setiap proses perjumpaan. Karena itu dalam membangun hubungan dengan konseli, maka ada beberapa hal yang harus diperhatikan oleh konselor:

\section{a. Hadir dalam Situasi Krisis}

Untuk mencapai hubungan dengan konseli maka konselor diharapkan hadir pada saat konseli berada dalam situasi krisis. Dalam proses ini konseli akan merasa ditopang dengan pendampingan konselor. Kekerasan yang dialami ibu RM dari hari ke hari membuatnya merasa tidak nyaman lagi tinggal di rumahnya itu. Dan puncak kekerasan itu dialami saat ia dilempar batu cobek, walaupun ia berhasil menghindarinya, semakin membuatnya berniat untuk meninggalkan suaminya. Wright, mengatakan bahwa beberapa akibat paling hebat dari suatu krisis ialah bunuh diri, melarikan diri, menyakiti diri sendiri, psikosis atau kehancuran keluarga karena itu pada tahap ini, konseling krisis sangat berfungsi untuk menopang konseli (Wright, 2006). Hal itu menunjukkan bahwa niat konseli untuk pergi dari rumah dan meninggalkan suaminya merupakan akibat dari puncak krisis yang dialami. Rasa sakit, kemarahan, kecewa, merasa takut dan terancam yang terkumpul selama mengalami kekerasan membuat konseli merasa tidak ada lagi gunanya bertahan dalam rumah tangganya. Ibu RM merasa bahwa rumah tangganya sudah hancur dan tidak bisa lagi dipertahankan. Dalam situasi demikian tentunya konseli sangat membutuhkan kehadiran seseorang untuk menolongnya supaya tidak sampai mengambil keputusan yang salah. Sebab orang yang sedang mengalami krisis biasanya keadaannya sangat rentan, karena keadaan sakit dan tertekan menyebabkan mekanisme masalah makin menurun (Wright, 2006).

Switzer, juga mengatakan hal yang serupa bahwa konseling krisis menolong konseli untuk mengurangi keadaan bahaya langsung dan menghentikan penyesuaian tingkah laku yang salah terhadap krisis (Switzer, 1974). Yang sering terjadi saat 
mengalami krisis adalah orang akan gegabah mengambil keputusan seperti bunuh diri, bercerai, dll sehingga keputusan-keputusan itu sering disesalkan kemudian. Dalam kasus ibu RM juga terlihat niat konseli untuk mengambil keputusan melarikan diri dan meninggalkan suaminya kemudian tidak jadi karena konseli tidak mau mengorbankan anaknya dalam persoalan rumah tangganya. Oleh karena itu salah satu tujuan dalam konseling krisis adalah menolong konseli mencegah kehancuran.

Dalam tahapan krisis ini, kehadiran konselor sangat diharapkan bersama konseli untuk memberikan dukungan emosi sehingga mengurangi kegelisahan, rasa bersalah dan ketegangan demi memulihkan kembali keseimbangan dalam diri konseli. Kehadiran konselor merupakan pelayanan yang sangat penting dan sangat berarti bagi konseli walaupun kehadiran itu bersifat nonverbal, namun sangat berarti dan memberikan rasa nyaman pada konseli (Stone, 1993). Seperti ibu RM yang datang berinisiatif menjumpai penulis untuk mendapatkan pertolongan melalui pelayanan konseling. Niat itu muncul karena ibu RM merasa tidak ada lagi tempat baginya untuk mencari pertolongan, karena dia sudah mencobanya kepada keluarga, sahabat, termasuk juga rekan kerjanya, tetapi ia tidak memperoleh 'jawaban' atas persoalan yang dihadapinya.

Supaya konselor mendapat kepercayaan konseli, maka konselor harus dapat membangun komunikasi yang baik sehingga konseli dengan tanpa ragu menyampaikan seluruh perasaannya atas krisis yang sedang dialami. Pada awal percakapan lewat telepon dan perjumpaan tatap muka dengan ibu RM, penulis berusaha menjalin komunikasi yang baik dengannya, sehingga hal ini dapat membangun kepercayaan ibu RM, yang pada akhirnya menceritakan semua pengalaman KDRT oleh suaminya terhadap penulis. Tentu tidak semudah yang dibayangkan untuk dapat menceritakan pengalaman ibu RM kepada orang lain (termasuk kepada penulis), karena ia seolah-olah membuka aib keluarganya sendiri yang seharusnya hal itu sangat mempermalukan keluarganya, khususnya suaminya.

Pada tahap ini penulis harus memperhatikan bahasa-bahasa tubuh yang ditunjukkan oleh konseli. Memperhatikan 'mata' si konseli ketika berbicara, sebab pandangan mata merupakan salah satu kekuatan dalam berkomunikasi dan menunjukkan bahwa kita sungguh-sungguh hadir untuk dia. Jika memungkinkan konselor bisa juga duduk di dekat konseli, memegang tangannya atau memeluknya (jika konselornya seorang perempuan). Namun karena dalam hal ini penulis sebagai konselor adalah seorang pendeta laki-laki, maka penulis tidak perlu melakukan hal tersebut. Artinya, tetap jaga jarak (physical distancing). Penulis hanya berusaha 
menenangkan konseli melalui perkataan "silahkan jika inang (ibu) ingin menangis", "silahkan inang (ibu) mengatakan apapun yang ingin inang (ibu) katakan saat ini”, "jika inang (ibu) sudah merasa lega dengan menangis, tarik nafas yang dalam supaya dapat menenangkan". Penulis juga memberikan air putih hangat kepada ibu RM. Bagi penulis hal-hal tersebut sangat menolong penulis sebagai konselor untuk tetap menjaga jarak dengan konseli dan konseli juga merasa nyaman. Kehadiran penulis dengan bertatap muka dengan ibu RM saat krisis, akan membuat ibu RM tidak merasa sendiri menghadapi permasalahannya. Walapun kehadiran itu tanpa banyak kata-kata namun dengan menunjukkan sikap empati melalui bahasa tubuh (body language), penerimaan penulis terhadap ibu RM akan sangat memberikan dukungan yang berarti bagi konseli.

\section{b. Mendengarkan}

Setelah konselor hadir dalam situasi kristis si konseli, maka langkah selanjutnya yang perlu dilakukan adalah mendengarkan. Dalam membangun hubungan yang baik dengan konseli, seorang konselor haruslah menjadi seorang pendengar yang baik karena mendengarkan merupakan salah satu keterampilan dasar dalam konseling. Stone mengutip Dietrich Bonhoeffer dalam $(1954,97)$ yang mengatakan: The first service that one owes to others in the fellowship consists in listening to them. Just as love of God begins with listening to His Word, so the beginning of love for (others) is learning to listen to them. It is God's love for us that He not only gives us His Word but also lends us His ear. So it is His work that we do for (others) when we learn to listen to them. Christians, especially minister, so often think they must always contribute something when they are in company of others, that is the one service they have ro render. They forget that listening can be a greater service than speaking (Stone, 1993).

Kutipan tersebut menegaskan bahwa pelayanan itu bukanlah diukur dengan pemberian materi kepada orang lain tetapi 'mendengarkan' mereka. Tahap 'mendengarkan' ini menjadi sangat penting dalam konseling krisis karena dengan mendengarkan, konselor akan menerima setiap informasi dan dapat memahami krisis yang dihadapi konseli sehingga konselor tertolong untuk melakukan pelayanan ini ke tahap berikutnya. Pekerjaan 'mendengarkan' ketika orang lain berbicara memang terkesan sangat sederhana dan mudah, tetapi terkadang tidak semudah yang kita bayangkan. Jika konselor tidak mendengarkan dengan baik setiap yang disampaikan oleh konseli, bisa saja konseli tidak akan nyaman dan mengakibatkan konseling tidak menolongnya. 
Ibu RM menyampaikan pengalamannya kepada penulis (bahkan hal yang sangat privasi sekalipun), walau pada awalnya penulis sempat merasa sedikit canggung karena penulis adalah seorang pendeta laki-laki. Namun karena penulis selalu berusaha untuk mendengarkan ibu RM dengan baik dan ini membuat ibu RM merasa tidak takut bahkan tidak malu sedikitpun untuk menceritakan semua pengalamannya kepada penulis. Terkait dengan ini sama seperti yang dikatakan oleh Boenhoeffer, bahwa mendengarkan menjadi pelayanan yang lebih baik daripada berbicara, maka konselor dituntut agar menjadi seorang pendengar yang baik (Switzer, 1974). Seorang konselor yang baik harus mempunyai kepekaan yang tinggi dan memperhatikan dengan seksama pesan yang disampaikan konseli baik verbal maupun nonverbal. Dalam hal ini konselor harus membuat mereka merasa nyaman ketika mereka menceritakan segala pengalamannya dan mendengarkannya dengan baik. Seorang konselor harus mendengarkan kisah para konseli dari sudut pandang mereka, untuk menemukan makna dari kisah-kisah mereka dan memberikan dukungan kepedulian atas kejadian yang mereka alami (Karl \& Bartsch, 2005). Mereka harus meyakini bahwa para konselor itu peduli kepada mereka, dapat dipercaya dan menjaga kepercayaan mereka, tidak mengkritik mereka atau memberikan saran atau solusi kilat, serta sungguh-sungguh mendengarkan dan mengerti rasa sakit mereka.

Bila orang yang didampingi percaya kepada pendamping, maka ia bersedia membuka diri lebih jauh dalam mengemukakan persoalannya. Bukan hal yang mudah bagi istri, korban KDRT untuk melangkah keluar mencari pertolongan atas masalah yang dihadapinya, apalagi ia hidup dalam budaya patriarkhal. Korban biasanya enggan untuk menceritakan masalahnya kepada orang lain karena malu persoalan rumah tangganya diketahui orang lain, ia akan merasa terbeban karena seolah membuka aib rumah tangganya. Selain itu faktor kepercayaan kepada konselor yang juga kadang membuat si korban/jemaat ragu untuk menceritakan persoalannya belum lagi kalau konseli akan disalahkan atas kekerasan yang dialami. Untuk itulah upaya korban KDRT dalam mencari pertolongan dan menceritakan pengalamannya sangat membutuhkan pertimbangan yang matang dan dengan kekuatan dan keberanian yang ekstra dari dirinya. Oleh karena itu konselor harus menghargai upaya korban KDRT yang datang kepadanya dengan menjadi pendengar yang baik dan dapat dipercaya.

Pada tahap ini, konselor diharapkan berperan aktif dalam menggali permasalahan orang yang didampingi. Dari pendampingan yang dilakukan penulis memberikan beberapa pertanyaan terbuka (open ended question) seperti: "Bisa inang (ibu) ceritakan lebih jauh...?" "Saya ingin tahu lebih banyak soal...." "Menurut inang 
(ibu) bagaimana...?" "Bagaimana perasaan inang (ibu)...?", dan sebagainya. Dalam rangka menggali masalah, konselor juga diharapkan mendengarkan secara aktif terhadap apa yang dikemukakan konseli supaya konselor dapat memahami semua proses krisis tersebut. Selain itu, keterampilan turunan dari mendengarkan di atas perlu digunakan pada tahap ini, guna memperoleh kejelasan duduk persoalan orang yang didampingi. Dengan memberikan kesempatan untuk berbicara tentang rasa sakit mereka, seseorang dapat memperoleh pengertian yang benar tentang apa yang terjadi dan bagaimana hal itu mempengaruhi mereka, menerima apa yang telah terjadi, mampu percaya kepada Allah, bersandar kepada-Nya dan mengizinkan Dia menyembuhkan mereka (Mzm. 62:9).

Apabila konseli sudah menyampaikan semua perasaannya atas kekerasan yang dialami, ia akan mengalami Katarsis, yaitu tahap dimana ia mampu melepaskan ketegangan-ketegangan dalam dirinya. Konseli yang menjadi korban KDRT biasanya memberikan reaksi yang negatif seperti kemarahan, kebencian dan kesedihan. Saat konseli menceritakan krisis yang dialami dengan luapan-luapan emosi itu, penulis memberikan ruang dan kesempatan untuk konseli mengeluarkan semua reaksi-reaksi tersebut. Penulis sebagai konselor berusaha untuk empati dan mencoba menenangkan konseli dengan aktif, terus mendengar konseli berbicara dan memiliki keyakinan bahwa konselor mampu mengatasi masalahnya.

\section{Memfokuskan masalah pada bagian yang paling penting}

\section{(Boiling down the problem to its essential)}

Setelah konseli mengalami katarsis maka konselor dan konseli membuat kesepakatan bersama untuk bekerja sama melihat masalahnya atau peristiwa sebelum krisis itu terjadi sampai saat krisis itu terjadi sehingga mereka dapat menciptakan suatu pemahaman tentang krisis apa yang sedang dihadapi konseli (Switzer, 1974). Dalam tahap ini fungsi pastoral sudah lebih ke arah membimbing di mana konseli akan merasakan penyembuhan jiwa yang mencapai pada kearifan yang lebih baik dan memperhadapkannya pada beberapa pilihan untuk dapat dipikirkan atau dilakukan (Stone, 1993). Proses ini akan menolong konseli melihat masalah itu lebih tenang dan jernih sehingga konseli dan konselor bersama-sama menyelidiki, mana aspek-aspek krisis kekerasan dan mana yang mengancam keselamatan korban. Seperti pengalaman ibu SP, segala bentuk kekerasan yang dialami mulai dari verbal dengan menghina, fitnah dan kekerasan fisik dengan menampar, memukul hingga terluka dan bahkan sampai membuatnya depresi dan trauma. Untuk menggali situasi 
krisis yang dialami korban, konselor juga dapat mengajukan beberapa pertanyaan yang lebih detail seperti: "Bagaimanakah perasaan inang (ibu) sekarang ini?" "Sejak kapan perasaan itu mulai inang (ibu) alami?" "Apakah ada sesuatu yang baru dari situasi kehidupan inang (ibu) sekarang ini?"

Setelah menggali ancaman yang dialami konseli maka konselor dapat menolong konseli untuk menentukan fokus masalah, ancaman yang mengakibatkan konseli berada dalam situasi krisis.(Stone, 1993) Setiap informasi yang disampaikan konseli dipilah-pilah mana yang berhubungan dengan peristiwa krisis dan mana yang tidak begitu ada kaitannya supaya duduk persoalan semakin jelas. Konselor juga dapat mengarahkan konseli untuk melihat suatu kejadian sebelum krisis itu terjadi (Beek, 2014). Bisa saja ada pemicu yang menyebabkan konseli mengalami krisis. Sebagaimana pengalaman ibu BL, setiap suami pulang ke rumah dalam keadaan mabuk, memaki dan memaksanya untuk memuaskan nafsu birahinya. Jika dilihat kejadian sebelum pulang ke rumah dan menimbulkan kekerasan yang hebat pada ibu $\mathrm{BL}$, ternyata hal ini disebabkan oleh suami yang telah kalah dalam berjudi. Kekalahan judi membuat suami konseli marah besar yang dilampiaskan kepada ibu BL setibanya di rumah. Dengan demikian konseli dapat mengetahui bahwa judi menjadi salah satu pemicu atas kekerasan yang dialami dari suaminya. Di samping itu konselor juga perlu menggali informasi tentang keterkaitan rumah tangga konseli dengan anggotaanggota keluarga yang lain, apakah ada hubungannya dengan suami konseli. Sedangkan dari kasus ibu TT, kita menemukan peran saudari yang mengintervensi suaminya dalam kehidupan rumah tangga mereka. Bentuk-bentuk intervensi itu perlu diketahui lebih jauh lagi dan bagaimana kaitannya dengan sikap suaminya yang melakukan kekerasan padanya. Setelah mengatahui hal itu maka konseli dan konselor dapat membicarakan bersama langkah apa yang dapat dilakukan selanjutnya.

\section{Menanggulangi masalah secara aktif}

\section{(Cope actively with the problem)}

\section{a. Menentukan Tujuan}

Yang pertama dilakukan dalam tahap ini adalah menentukan secara bersama apa yang menjadi tujuan dari penyelesaian masalah tersebut. Karena konseling krisis bertujuan untuk mengatasi situasi krisis dan biasanya dilakukan dalam waktu yang pendek (sekitar enam minggu), maka konselor harus berusaha mengarahkan konseli untuk menetapkan tujuan yang memungkinkan untuk dicapai. Jauh lebih baik jika menetapkan tujuan sederhana dalam jangka waktu singkat dan tercapai daripada 
menetapkan tujuan yang sangat besar dengan waktu yang panjang tetapi tidak dapat tercapai karena hal itu akan membuat konseli kecewa. Konselor dapat meminta kesediaan konseli untuk mengutarakan apa yang diharapkan dari konseling tersebut, seperti dalam kasus KDRT yang dialami ibu TT dan RS tersebut, tujuan konselingnya bagaimana supaya ia tidak meninggalkan suaminya karena perlakuan kekerasan yang dihadapi. Demikian pun terhadap ibu BL, RS dan SP, tujuan konselingnya bagaimana supaya mereka dapat berusaha mandiri dengan bekerja, supaya dapat memenuhi kebutuhan hidup keluarga. Sehingga konselor dapat melakukan konseling dengan mengarahkan si konseli pada tujuannya.

Namun berbeda halnya dengan kasus ibu RM, yang tadinya konseling bertujuan bagaimana supaya ia tidak meninggalkan suaminya, namun seiring berjalannya waktu, akhirnya ia memilih untuk pisah rumah, dengan alasan yang cukup panjang, dimana ia merasa keluarga dari pihak suaminya sudah tidak memperdulikan rumah tangga mereka, ditambah lagi suaminya sendiri tidak menghargainya sebagai istri, dan hal ini didukung pula dengan tidak/belum adanya berkat keturunan di rumah tangga mereka. Ibu RM menambahkan lagi, daripada ia akan mengalami kejadian yang serupa dalam hal kekerasan, lebih baik ia untuk sementara ini pisah rumah saja dengan suami. Dalam hal menentukan tujuan ini, sepertinya teori ini tidak/belum berhasil mengena kepada kasus kekerasan yang dialami oleh ibu RM.

\section{b. Menginventarisasi sumber-sumber yang dimiliki konseli untuk menanggulangi masalah}

Pada tahap ini konselor dapat membimbing korban dan memberikan gambaran tentang kekuatan dan kelemahan konseli dalam mengatasi kekerasan yang dialami (Stone, 1993). Konselor membantu konseli untuk menyadari adanya kekuatan dalam dirinya untuk menangani masalahnya sehingga konseli menyadari bahwa solusi atas masalahnya menjadi tanggungjawabnya. Karena itu salah satu prinsip dasar dalam konseling krisis ini adalah: janganlah berbuat sesuatu apa pun untuk konseli, kalau ia sendiri memang mampu melakukannya (Wright, 2006). Oleh karena itu dalam tahap ini konseli dan konselor perlu menentukan atau menginventarisasi apa-apa saja sumber internal dan eksternal yang dimiliki konseli yang dapat menolongnya dalam mengatasi masalahnya (Beek, 2014).

Dari pengalaman ibu TT kita dapat melihat bagaimana ia mampu menghadapi krisis akibat kekerasan dalam rumah tangga yang dialami. Keberanian dan kemampuan itu tentu tidak datang begitu saja pada konseli. Proses yang panjang dari 
lingkaran kekerasan yang dialami telah membentuknya menjadi seorang yang kuat dan berani menghadapi kenyataan hidup. Salah satu cara ibu TT menanggulangi krisis yang dihadapi adalah dengan menghadiri persekutuan doa di lingkungan rumah tempat ia tinggal. Dalam persekutuan itu konseli semakin dikuatkan oleh ibu Majelis yang membimbingnya selalu sehingga konseli mampu menghadapi krisis itu. Melalui bimbingan dari pelayan gereja atau siapa pun itu, konseli akan ditolong untuk memahami bahwa betapa berharganya dirinya di hadapan Tuhan yang Mahakasih. Konseli akan semakin dikuatkan untuk berani menghadapi krisis itu. Sangat dapat dipahami bahwa dalam situasi demikian konseli akan merasa harga dirinya rendah seperti sikap ibu TT yang akhirnya menarik diri dari aktivitas di gerejanya karena ia malu dengan KDRT yang dialami di rumah tangganya. Karena itu konseli harus dituntun untuk melindungi dan meningkatkan citra dirinya sehingga ia merasa dihargai dan dihormati.

Konselor juga dapat memberikan pertimbangan kepada konseli untuk melakukan sesuatu yang dapat ia lakukan, kira-kira apa hal yang diminati dan memungkinkan untuk dikerjakan. Seperti kemampuan konseli yang bisa berjualan sehingga membuka usaha dagang di rumah sebagai cara untuk menambah kebutuhan rumah tangganya, seperti yang dialami oleh ibu RS dan ibu BL. Demikian pun terhadap ibu TT, berbekal kemampuan "memijat" juga membuatnya membuka jasa pijat di rumahnya sebagai salah satu cara untuk mengatasi kekurangan kebutuhan di keluarganya. Sumber lain dalam pemecahan masalah juga bisa didapat dari luar diri konseli seperti keluarga, anak-anak, orang tua, teman/sahabat, pelayan, dll. Peranan anak-anaknya tentu sangat memberikan kekuatan kepada ibu BL, TT, RS dan SP dalam menghadapi masa-masa krisis nya. Bahkan ketika konseli berpikir hendak meninggalkan suaminya, anak-anak menjadi alasan untuk tidak melakukan tindakan itu. Konseli tidak mau mengorbankan anak-anak dalam krisis yang dialami. Walaupun memiliki suami yang bersikap keras kepadanya tetapi konseli tetap merasa bahwa suaminya sangat dibutuhkan oleh anak-anaknya. Demikian juga ketika konseli yang masih trauma dengan suaminya walaupun sudah tidak ada lagi, anak-anak juga yang menolongnya untuk bisa sembuh dari traumanya.

\section{c. Menentukan Tindakan}

Setelah menentukan tujuan dan menginventarisasi sumber internal dan eksternal yang dimiliki konseli maka saatnya mengambil tindakan. Semua langkah yang sudah dilakukan dari awal konseling ini akan sia-sia jika konseli tidak melakukan 
tindakan. Howard Stone mengutip yang dikatakan O. Hobart Mowrer yang mengatakan "It is easier to act your way into a new way of feeling than to feel your way into a new way of acting" atau dalam kutipannya Clinbell's (Clinbell 1966, 171) mengatakan bahwa, "The person's personality or self is like a muscle. When you use a muscle it grows stronger... if you don't use the muscle the muscle begins to atrophy and waste away" (Stone, 1993). Oleh karena itu konselor harus mendorong konseli untuk melakukan sesuatu atas masalah yang sedang dihadapi supaya konseli mengalami perkembangan dalam menghadapi persoalannya.

Dalam kasus ibu SP, konselor membantu konseli untuk menentukan sumber yang mana dan memungkinkan untuk digunakan dalam menanggulangi masalahnya yang sering muncul niat untuk meninggalkan suaminya sehingga konseli dapat menentukan tindakan yang akan dilakukan dan sembari konselor terus mengarahkan konseli pada tujuannya. Dalam hal ini konseli memiliki kebebasan untuk memilih dan menentukan tindakan mereka atas masalahnya atau bahkan untuk tidak melakukan apa-apa sekalipun. Ibu SP memilih menjalankan bisnis berdagang perabotan rumah tangga dan bisnis jual beli berlian, sehingga ia tidak selalu terfokus pada pikiran-pikiran yang dapat membuatnya meninggalkan suaminya. Dengan demikian konseli tidak ketergantungan pada konselor karena dia menemukan sendiri cara dan tindakan yang dilakukan dalam menghadapi krisis tersebut. Namun konselor juga dapat menolong konseli untuk melakukan apa yang bisa dilakukan untuk membantu konseli mencapai tujuannya dengan cara apa pun yang bisa dilakukan konselor (kecuali dalam keadaan darurat yang tidak bisa lagi dilakukan konselor), misalnya konselor dapat memberikan rumahnya menjadi tempat persinggahan konseli sementara menghindari pemukulan yang dilakukan suaminya.

\section{d. Evaluasi}

Untuk mengakhiri sesi konseling yang sudah berlangsung dalam jangka waktu tertentu, perlu dilakukan evaluasi apakah tujuan dapat tercapai dan tindakan yang dipilih itu efektif dalam menyelesaikan krisis. Kemudian dalam evaluasi perlu juga mengulas kembali dari kejadian yang sudah lewat untuk menemukan cara menghadapi persoalan atau krisis di masa ke depan yang pasti akan terjadi.

\section{KESIMPULAN}

Kekerasan terhadap istri yang terjadi di jemaat HKBP, yang penulis tangani, telah mengakibatkan luka secara fisik dan psikis. Luka secara fisik berupa pukulan, 
tamparan dan kata-kata hinaan yang dilontarkan oleh pelaku (suami) bagi si korban (istri). Luka secara psikis menimbulkan stress, yang selanjutnya mengakibatkan depresi dan pengalaman traumatis. Hal ini membuat perempuan korban KDRT menjadi menderita.

Tuhan Allah tidak menghendaki kekerasan dan penderitaan terjadi pada manusia, khususnya perempuan (istri). Karena secara teologis, perkawinan merupakan inisiatif Tuhan Allah sendiri (Kej. 1:27-28, Kej. 2:18), supaya laki-laki dan perempuan yang diciptakan-Nya menjadi satu daging (Kej. 2:24) dan hidup saling mengasihi dan menghormati (Ef. 5:22, 25; Kol. 3:18-19). Yesus juga memberikan gambaran mengenai Kerajaan Allah seperti sebuah keluarga yang bahagia, mencintai, dan bukan sebuah kerajaan yang menaklukkan dan menindas (Mat. 22:39b; Mrk. 12:31a; Luk. 10:27b; Yoh. 15:17) (Nolan, 2009).

Perempuan korban KDRT sangat membutuhkan dukungan konselor yang terlatih untuk proses penyembuhan. Hal ini bertujuan agar mereka dapat menyikapi dengan cara berpikir dan siap yang benar. Jika perempuan korban KDRT tidak menyadari betapa parahnya situasi yang dialami, seperti kemarahan, kebingungan, rasa sakit, rasa malu, yang berakibat depresi dan menimbulkan pengalaman traumatis, maka ia tidak bisa sembuh dari situasi tersebut. Oleh karenanya dibutuhkan pendampingan pastoral yang dapat membantu perempuan korban KDRT, bukan hanya dalam fungsi pastoral menopang (sustaining), mendamaikan (reconciling), dan menyembuhkan (healing), akan tetapi dalam proses pendampingan tersebut penulis juga menemukan peran fungsi pastoral membimbing (guiding).

\section{DAFTAR PUSTAKA}

Auld, A. G. (2017). Pemahaman Alkitab Setiap Hari- Yosua, Hakim-hakim dan Rut. BPK Gunung Mulia.

Beek, A. Van. (2014). Pendampingan Pastoral. BPK Gunung Mulia.

Bergant, D., \& Karris, R. J. (2014). Tafsir Alkitab Perjanjian Lama. Kanisius.

Bria, B. Y. (2003). Kekerasan Terhadap Perempuan dan Bagaimana Menyikapinya. Yayasan Putra Nusantara.

Fiorenza, E. S. (2001). Wisdom Ways: Introducing Feminist Biblical Interpretation. Orbins Books.

Greist, J. H., \& Jefferson, J. W. (1998). Depresi dan Penyembuhannya. BPK Gunung Mulia.

Gunarsa, Y. S., \& Gunarsa, S. (2012). Psikologi untuk Keluarga. BPK Gunung Mulia.

Hatta, K. (2016). Trauma dan Pemulihan: Suatu kajian berdasarkan Kasus Pasca Konflik dan Tsunami. Dakwah Ar-Raniry Press.

Henry, M. (2000). Commentary on the Whole Bible Volume V. Christian Classics Ethereal Library.

HKBP, K. P. (2000). Ruhut Parmahanion dohot Paminsangon HKBP. Percetakan 
HKBP.

HKBP, K. P. (2013). Panindangion Haporseaon 1951 \& 1996. Pematangsiantar. Percetakan HKBP.

Karl, \& Bartsch, E. (2005). Sang Terluka yang Menyembuhkan, Stress dan Trauma Healing. Penerbit Pusaka Muria.

Koentjoro, \& Andayani, B. (2007). Recovery Kawasan Bencana: Perwujudan Trauma Healing Melalui Kegiatan Psikologi dan Rohani. Unisia.

Lubis, N. L. (2016). Depresi Tinjauan Psikologi. Kencana.

Moltman, J. (1993a). The Crucified God: The Cross of Christ as the Foundation and Criticism of Christian Theology. Fortress Press.

Moltman, J. (1993b). Theology of hope: The Cross of Christ as the Foundation and Criticism of Christian Theology. Fortress Press.

Nainggolan, T. (2012). Batak Toba: Sejarah dan Transformasi Religi. Bina Media Perintis.

Nolan, A. (2009). Jesus Today: Spiritualitas Kebebasan Radikal. Kanisius.

Pakpahan, B. J. (2016). The Power of Shame: Mengembalikan Malu Spiritual. BPK Gunung Mulia.

Ririmasse, M. (2019). Perempuan, Kekerasan \& Perdamaian: Sebuah Refleksi Teologis Feminis. Yakoma PGI-Persetia-Mission 21.

Rosenbloom, D., Williams, Beth, M., \& E, B. (2010). Life After Trauma: Second Edition A Workbook for Healing. The Guilford Press.

SEAGEST. (1993). Studi Kasus Pastoral. BPK Gunung Mulia.

Stone, H. W. (1993). Crisis Counseling. Fortress Press.

Subagyo, A. B. (2003). Tampil Laksana Kencana: Pertolongan untuk Mencegah dan Mengatasi Krisis Sepanjang Hidup. Yayasan Kalam Hidup.

Susanto, D. (2020). Pendampingan Pastoral Terhadap Orang Lansia Dalam Memaknai Hidup Di Masa Tua. In Bunga Rampai Pastoral Keluarga. BPK Gunung Mulia.

Switzer, D. K. (1974). The Minister as Crisis Counselor. Abingdon Press.

Walker, L. E. (1979). The Battered Woman. Harper \& Row Publisher.

Wright, N. H. (2006). Konseling Krisis. Gandum Mas. 